\title{
SUMBER BELAJAR SEJARAH: PEMANFAATAN SITUS CAGAR BUDAYA DI MINAHASA
}

\author{
Aldegonda Evangeline Pelealu \\ Email: aldegonda_pelealu@unima.ac.id \\ Jurusan Pendidikan Sejarah Fakultas Ilmu Sosial Universitas Negeri Menado
}

\begin{abstract}
Abstrak
Penelitian ini bertujuan untuk menjelaskan situs cagar budaya apa saja di Minahasa yang digunakan sebagai sumber belajar sejarah Indonesia dan menjelaskan bagaimana proses pemanfaatan situs cagar budaya di Minahasa sebagai sumber belajar sejarah mata kuliah Pra Sejarah Indonesia mahasiswa semester I Jurusan Pendidikan Sejarah FIS UNIMA. Metode penelitian yang digunakan adalah metode penelitian Sejarah menurut Marc Bloch. Hasil penelitian menunjukkan Situs Cagar budaya di Minahasa adalah "Waruga"(kubur batu), dan "watu tumotoa". Waruga adalah kubur batu dari zaman batu bagi orang Minahasa. Karena itu, kubur batu itu tersebar diberbagai daerah/wilayah di Minahasa. Sedangkan "watu tumotowa" atau "batu Manguni" juga terdapat di beberapa kampung sebagai tanda tempat leluhur mendengarkan suara burung Manguni. Proses pemanfaatan situs cagar budaya di Minahasa sebagai sumber belajar Sejarah Indonesia dapat dilakukan dengan 2 (dua) cara. Pertama, dapat langsung membelajarkan mahasiswa pada obyeknya dilakukan mahasiswa dengan mendapatkan bimbingan dosen. Khusus untuk mahasiswa dapat pula dilakukan dalam bentuk penugasan dosen secara kelompok dengan mengunjungi situs cagar budaya yang dekat dengan kampus. Namun demikian, cara pertama ini harus dilakukan melalui suatu perencanaan pembelajaran oleh dosen secara tepat pada topik yang relevan seperti topik zaman batu. Kedua, membelajarkan mahasiswa melalui foto atau gambar yang telah disiapkan dosen. Cara pembelajaran pertama dan kedua harus didahului dengan informasi dari dosen kepada mahasiswa.
\end{abstract}

Kata Kunci : Situs cagar budaya, sumber belajar

\section{Pendahuluan}

Minahasa adalah salah satu Kabupaten yang ada di Provinsi Sulawesi Utara yang memiliki berbagai situs cagar budaya yang merupakan peninggalan sejarah yang sangat penting artinya sebagai sumber belajar sejarah Indonesia. Mata kuliah Pra Sejarah Indonesia mempelajari tentang sejarah zaman batu dan salah satunya adalah bangunan-bangunan batu besar sebagai tempat pembagian wilayah seperti Watu Pinabetengan yang ada di Pinabetengan yang memiliki nilai sejarah dimana tokoh-tokoh masyarakat membagi wilayah Minahasa, Waruga sebagai tempat pemakaman orang Minahasa, Watu Tumotowa sebagai tempat pemujaan, Watu Menhir sebagai tempat pemujaan, Lesung Batu yang ada di daerah Kakas. Situs Cagar budaya tersebut di atas merupakan sumber belajar Sejarah dan mahasiswa diharapkan mengetahui peninggalan719 | Seminar Nasional Sejarah ke 4 Jurusan Pendidikan Sejarah Universitas Negeri Padang 
peninggalan sejarah tersebut yang ada di sekitar kampus sebagai bukti bahwa di Minahasa pernah mengalami zaman batu besar.

Cagar budaya sebagai salah satu warisan leluhur apabila dipahami secara mendalam melalui proses belajar yang tekun, maka akan sangat membantu dalam membentuk nilai-nilai sehingga tercipta suatu nuansa kepemilikan dan kebanggaan akan budaya bangsa.

Penggunaan peninggalan sejarah di Minahasa sebagai sumber belajar sejarah sangat penting, dan perlu memahami lebih dahulu peninggalan situs cagar budaya yang ada di daerah terdekat, dan lebih mudah dibandingkan mengetahui peninggalan yang ada di daerah lain yang membutuhkan biaya yang besar. Sebab itu setiap perkuliahan Mata Kuliah Pra Sejarah Indonesia selalu diadakan kunjungan lapangan ke lokasi-lokasi yang memiliki situs cagar budaya sebagai bukti bahwa peninggalan situs budaya zaman batu masih terpelihara dengan baik dan dijadikan sebagai sumber belajar untuk lebih memahami dan menguasai materi yang telah diajarkan.

Tujuan penelitian untuk menjelaskan situs cagar budaya apa saja di Minahasa yang digunakan sebagai sumber belajar sejarah Indonesia serta menjelaskan bagaimana proses pemanfaatan situs cagar budaya di Minahasa sebagai sumber belajar sejarah mata kuliah Pra Sejarah Indonesia mahasiswa Jurusan Pendidikan Sejarah FIS UNIMA.

\section{Metode Penelitian}

Penelitian ini menggunakan metode penelitian Sejarah menurut Marc Bloch. Teknik pengumpulan data yang telah dilakukan dengan menggunakan studi kepustakaan, dengan menerapkan langkahlangkah metode sejarah Marc Bloch..Teknik Analisis Data menggunakan teknik analisis kritik sejarah, generalisasi dan kategorisasi data/fakta, kemudian mengadakan analisis interpretasi

\section{Hasil Dan Pembahasan}

A. Situs Cagar Budaya di Minahasa dan Penggunaan sebagai sumber belajar sejarah Indonesia

a. Situs Cagar Budaya di Minahasa

Situs Cagar budaya di Minahasa yang menjadi fokus penelitian pertama bernama "Waruga"(kubur batu), dan kedua, "watu tumotoa"). Waruga adalah kubur batu dari zaman batu bagi orang 720 | Seminar Nasional Sejarah ke 4 Jurusan Pendidikan Sejarah Universitas Negeri Padang 
Minahasa. Karena itu, kubur batu itu tersebar diberbagai daerah/wilayah di Minahasa. Bahkan keberadaannya di sekitar pemukiman masyarakat(penduduk). Sedangkan "watu tumotowa" atau "batu Manguni” juga terdapat di beberapa kampung sebagai tanda tempat leluhur mendengarkan suara burung Manguni. Sehingga "watu tumotowa" ini ada kaitannya tempat mendengar suara yang memberikan petunjuk bahwa lokasi tersebut yang dapat dibangun kampung.

Seiring perkembangan zaman dan adanya pengaruh luar(asing-Barat), terutama orang Belanda, kebiasaan mngubur orang yang telah meninggal dalam kubur batu di Minahasa, dan berada disekitar rumah-rumah penduduk, mengalami perubahan. Perubahan yang dilakukan berdasarkan alasan kesehatan dan agama maka orang yang sudah meninggal di kubur pada tempat khusus yang disebut lahan/ladang pekuburan.

Jauh kemudian situs-situs cagar budaya berupa waruga yang tersebar di sejumlah lokasi di Minahasa, diusahakan untuk dikumpulkan dalam satu lokasi. Usaha mana dilakukan pada masa pemerintahan H.V.Worang sebagai Gubernur Provinsi Sulawesi Utara. Hasil usaha ini yang terlihat pada lokasi cagar budaya "waruga" di Sawangan-Airmadidi Kabupaten Minahasa Utara. Sejumlah waruga yang tersebar pada beberapa wilayah di Minahasa, dikumpulkan pada lokasi tersebut. Namun demikian, ada juga "waruga" yang masih tertinggal di lokasi asalnya sampai kini. Begitu pula, "watu tumotowa" masih terdapat pada tempat semula ditancapkan berdirinya oleh leluhur kampung tersebut.

Dengan demikian, situs-situs cagar budaya Minahasa seperti kubur batu -"waruga" dan batu Manguni "watu tumotowa" sebagai sumber belajar sejarah bagi mahasiswa, khususnya dalam mata kuliah "Prasejarah Indonesia", cukup tersedia. Ketersediaan situs-situs budaya itu, baik yang ada di lokasi cagar budaya Sawangan Airmadidi Kabupaten Minahasa Utara, Benteng Moraya maupun yang terdapat pada sejumlah tempat di Minahasa.

Selain para mahasiswa Jurusan Pendidikan Sejarah FIS Unima di Tondano, yang menggunakan situs-situs cagar budaya tersebut sebagai sumber belajar pra sejarah Indonesia, para guru sejarah di sekolah(SMA/SMK dan sekolah sederajat), oleh para gurunya dapat menggunakan situs-situs cagar budaya Minahasa yang lokasinya berdekatan dengan sekolah sebagai sumber belajar sejarah pada topik-topik yang relevan. Sehingga apa yang dipelajari para siswa tidak terasa asing, karena 
bukti-bukti budaya masyarakat di masa lampau, khususnya zaman pra sejarah dapat dilihat buktinya secara konkrit.

\section{b. Penggunaan Situs Cagar Budaya sebagai sumber belajar Sejarah Indonesia}

Penggunaan situs cagar budaya sebagai sumber belajar sejarah Indonesia, khususnya pra sejarah Indonesia, akan memberikan wawasan kepada mahasiswa tentang hasil karya leluhur pada zaman. Pada konteks kajian ini, yakni cara penguburan orang yang meninggal dan penandaan suatu tempat sebagai lokasi pendirian kampung atau tempat pemukiman.

Kedua situs cagar budaya berupa "waruga" dan "watu tumotoa" akan memberikan berbagai informasi yang dapat dinterpretasi dari wujud benda fisik tersebut. Sebagai contoh, dari segi pembuatan waruga dan watu tumotoa. Apakah sama batu sebagai bahan dasarnya? Jika tidak sama bahannya, mengapa? Bagaimana bentuknya?

Pada kenyataannya, memang bahan pembuatan kubur batu-"waruga" berbeda dengan bahan batu untuk "watu tumotoa". Batu untuk membuat "waruga" seperti batu kapur atau tras('domatu'bahasa lokal), sedangkan batu untuk membuat "tumotoa", ada yang bahannya seperti batu domatu dan atau jenis batu yang keras dan hitam. Tidak tampak banyak terlihat aktivitas mengubah fisik "watu tumotoa" seperti yang tampak pada "waruga".

\section{B.Proses pemanfaatan situs cagar budaya di Minahasa sebagai sumber belajar sejarah Indonesia}

\section{a. Proses Pemanfaatan Situs Cagar Budaya di Minahasa}

Pemanfaatan situs cagar budaya berupa "waruga" dan "watu tumotoa" sebagai sumber belajar sejarah Indonesia, dapat dilakukan dengan 2 (dua) cara. Pertama, dapat langsung membelajarkan mahasiswa pada obyeknya. Kedua, membelajarkan mahasiswa melalui foto atau gambar yang telah disiapkan dosen.

Cara pembelajaran yang pertama, dapat dilakukan mahasiswa dengan bimbingan dosen. Khusus untuk mahasiswa dapat pula dilakukan dalam bentuk penugasan dosen secara kelompok dengan mengunjungi situs cagar budaya yang dekat dengan kampus. Namun demikian, cara pertama ini 
harus dilakukan melalui suatu perencanaan pembelajaran oleh dosen secara tepat pada topik yang relevan seperti topik zaman batu.

Perencanaan itu terkait penetapan lokasi situs budaya "waruga" dan "watu tumotoa", waktu dan lamanya kunjungan, tujuan dan hasil yang diharapkan serta kegiatan yang dilakukan dilokasi. Yang tidak kalah pentingnya ialah pemberitahuan kepada penjaga dan atau masyarakat sekitar lokasi tempat situs budaya tersebut berada.

Cara pembelajaran pertama dan kedua harus didahului dengan informasi dari dosen kepada mahasiswa. Dalam informasi awal itu telah dikemukakan kegiatan yang akan dilakukan di lokasi sesuai sejumlah pertanyaan kritis yang dijawab dengan melalui pengamatan pada situs budaya "waruga" dan "watu tumotoa". Hal ini dilakukan searah dengan perubahan filsafat pembelajaran pendidikan sejarah.

Menurut Hamid Hasan (1999:4-11) seperti juga dikutip Dadang Supardan (2005:83) pembelajaran sejarah tidak saja menjadi wahana pengembangan kemampuan intelektual dan kebanggaan masa lampau, tetapi juga menjadi wahana dalam upaya memperbaiki kehidupan sosial, politik, ekonomi, yang sedang berlangsung. Pembelajaran sejarah memiliki nilai praktis dan pragmatis bagi siswa. Lebih lanjut, dikemukakan bahwa adanya pergeseran filsafat pembelajaran sejarah tersebut telah menuntut kepada tiga hal baru : (1) keterkaitan pelajaran sejarah dengan kehidupan siswa sehari-hari; (2) pemahaman karakteristik cerita sejarah yang tidak pernah bersifat final, sesuai dengan temuan fakta baru; dan (3) adanya perluasan tema sejarah politik dengan tema sejarah sosial, budaya, ekonomi, dan teknologi.

Beberapa pertanyaan yang dapat disusun oleh guru atau dosen untuk siswa/mahasiswa mengamati situs dan berusaha menyusun jawaban mereka sebagai berikut. "Mengapa orang Minahasa zaman purba mengubur jenasah dalam batu yang disebut waruga? Mengapa ada perbedaan bentuk waruga? Apa makna gambar atau relief pada dinding dan penutup waruga? Jelaskan nilai sosial, ekonomi, politik, dan budaya dalam pembuatan waruga itu? Mengapa bentuk dan bahan pembuatan "watu tumotoa" berbeda pada satu lokasi dengan lokasi lain? Apa fungsi "watu tumotoa" bagi masyarakat purba Minahasa kala itu? Apa relevansi "watu tumotoa" bagi masyarakat dewasa ini yang berada di sekitar lokasi?” Pertanyaan-pertanyaan lain dapat diajukan 
sebagai masalah untuk mendorong mahasiswa berpikir kritis, dan sekaligus menjadikan mereka sebagai pembelajar yang aktif dalam proses pembelajaran sejarah.

Cara belajar yang kedua, memerlukan persiapan guru dan atau dosen untuk menghadirkan gambar/foto situs budaya "waruga" dan "watu tumotoa" di kelas. Cara belajar yang kedua ini berbeda dengan cara pertama hanya pada obyek situs budaya tersebut, dimana pada cara kedua siswa/mahasiswa belajar mengamati melalui gambar/foto. Sedangkan pada cara pertama, mahasiswa belajar lewat pengamatan terhadap obyek langsung. Pada cara kedua ini, sejumlah juga disiapkan guru/dosen untuk diamati siswa atau mahasiswa. Gambar/foto disusun dan dipampankan pada papan display atau pada kertas yang berukuran lebar dan panjang. Maksudnya, untuk memberikan ruang gerak yang cukup pada para siswa/mahasiswa melakukan pengamatan pada gambar/foto guna mendapatkan informasi yang dapat disusun dalam menjawab pertanyaanpertanyaan penugasan dari dosen.

\section{b. Situs Budaya sebagai Sumber Pembelajaran Sejarah Indonesia}

Sumber belajar dalam pengertian sempit diartikan sebagai semua sarana pengajaran yang menyajikan pesan secara edukatif baik visual saja maupun audiovisual, misalnya buku-buku dan bahan tercetak lainnya. Pengertian ini masih banyak disepakati oleh guru dewasa ini. Misalnya, dalam program pengajaran yang biasa disusun oleh para guru, kompenen sumber belajar pada umumnya akan diisi dengan buku teks atau buku wajib yang dianjurkan.

Ada juga yang mengatakan bahwa sumber belajar yaitu segala sesuatu yang dapat memberikan informasi atau penjelasan, berupa definisi, teori, konsep, dan penjelasan yang berkaitan dengan pembelajaran. Sedangkan menurut Edgar Dale, dia berpendapat bahwa yang disebut sumber belajar itu pengalaman. Seperti pengalaman langsung dan bertujuan, pengalaman tiruan, pengalaman dramatis, pengalaman darmawisata, pengalaman pameran dan museum dan masih banyak lagi. Ini bias dilihat dalam buku Pengelolaaan Pengajaran karya Ahmad Rohani, disitu Edgar mengklasifikasikan pengalaman yang dapat dipakai sebagai sumber belajar menurut jenjang tertentu yang berbentuk cone of experience atau kerucut pengalaman yang disususn dari yang konkrit sampai yang abstrak(Ahmad Rohani, 2004:162). 
Kategorisasi Sumber Belajar bagi peserta didik untuk melakukan proses perubahan tingkah laku. Misalnya, dari tidak terampil menjadi terampil, dan tidak mengerti menjadi mengerti, dari tidak tahu menjadi tahu, dan menjadikan individu dapat membedakan mana yang baik dan tidak baik, mana yang terpuji

dan yang tidak terpuji dan seterusnya. Dengan demikian sesungguhnya banyak sekali sumber belajar pada masa sekarang dan juga dahulu yang terdapat dimana-

mana dan biasa kita gunakan kapan saja. Misalnya, di sekolah, museum, halaman, pusat kota, pedesaan dan sebagainya. Namun untuk pemanfaatan sumber pembelajaran dan pengajaran tersebut amat bergantung juga pada waktu dan biaya yang tersedia, kretifitas guru serta kebijakan-kebijakan lainnya.

Kategorisasi Sumber Belajar Karena sumber belajar memiliki pengertian yang sangat luas, maka dibawah ini dijelaskan mengenai apa saja yang termasuk kategori yang biasa disebut sebagai sumber belajar.

(a) Tempat atau lingkungan sekitar yaitu dimana saja seseorang dapat melakukan belajar atau proses perubahan tingkah laku maka tempat itu dapat dikategorikan sebagai tempat belajar yang berarti sumber belajar. Misalnya perpustkaan, pasar, museum, tempat pembuangan sampah, kolam ikan dan sebagainya.

(b) Benda/ pesan non formal, yaitu segala benda yang memungkinkan terjadinya perubahan tingkah laku bagi peserta didik atau pesan yang ada di lingkungan masyarakat luas yang dapat digunakan sebagai bahan pembelajaran. Misalnya situs, prasasti, relief- relief pada candi, kitab kitab kuno dan benda peninggalan lainnya termasuk juga ceramah oleh tokoh masyarakat dan ulama, cerita rakyat dan legenda(Wina Sanjaya, 2011: 228).

(c) Orang, yaitu siapa saja yang memilki keahlian tertentu dimana peserta didik dapat belajar sesuatu. Misalnya guru, polisi, ahli geologi dan ahli-ahli lainnya.

(d) Buku/bahan, yaitu segala macam buku yang dapat dibaca secara mandiri oleh peserta didik atau format yang digunakan untuk menyimpan pesan pembelajaran(Wina Sanjaya, 2011: 229). Misalnya buku pelajaran, buku teks, kamus, ensiklopedia, fiksi dan lain sebagainnya. 
(e) Peristiwa dan fakta yang sedang terjadi, misalnya peristiwa bencana, peristiwa kerusuhan, dan peristiwa lainnya yang guru dan murid dapat menjadikan peristiwa atau fakta sebagai sumber belajar(Abdul Majid, 2008:170).

Pemanfaatan situs sejarah sebagai sumber belajar dimaksudkan agar pembelajaran dapat memanfaatkan aspek dari lingkungan sebagai pendukung dari keberhasilan pendidikan di sekolah. Artinya semua yang ada di lingkungan

bias dijadikan sebgai sumber belajar yang dapat dimanfaatakan oleh siswa tidak terkecuali pada situs sejarah. Hal ini juga dapat meningkatkan potensi siswa dalam mengembangkan dirinya dalam suatu pembelajaran sejarah(Rahman Arif, 2017).

Dalam kerangka pemanfaatan situs sejarah atau situs budaya seperti waruga dan watu tumota sebagai Sumber Belajar, muncul pertanyaan : "Mengapa situs sejarah atau situs budaya dijadikan sebagai sumber belajar? Jawaban karena situs sejarah atau budaya merupakan lingkungan belajar yang diciptakan khusus untuk mempengaruhi atau memberikan rangsangan terhadap individu dan sebaliknya individu memberikan respons terhadap lingkungan. Maka itulah yang kemudian dinamakan belajar. Ada sebuah interaksi dalam sebuah proses belajar, dan dari interaksi itu data terjadi perubahan pada diri indivisu berupa perubahan tingkah laku. Lingkungan belajar sendiri bisa berupa lingkungan sosial, lingkungan personal, lingkungan alam (fisik), dan lingkungan kultural.

Dan situs - situs sejarah merupakan lingkungan alam (fisik) yakni biasa berupa museum, candicandi, dan relief-relief sejarah. Alam sekitar adalah segala sesuatu yang ada disekitar kita. Pengajaran berdasarkan alam sekitar akan membantu anak didik untuk menyesuaikan dirinya dengan kedaan sekitarnya. Ovide Decroly dikenal dengan teorinya, bahwa "sekolah adalah dari kehidupan dan untuk kehidupan" ( Ecole pour la vie parlavie ). Dikemukakan, bahwa "bawalah kehidupan kedalam sekolah agar kelak anak didik dapat hidup di masyarakat." Pandangan tersebut sedikit menggambarkan bahwa lingkungan merupakan dasar pendidikan/ pengajaran yang sangat penting(Oemar Hamalik, 1985:194).

Sejarah akan menjadi pelajaran yang membosankan jika dalam kegiatan pembelajarannya tidak dilakukan dengan metode yang inovatif dan menarik. Situs sejarah dapat menjadi alternatif dalam mengatasi masalah tersebut. Sebab dalam hal ini siswa akan mengalami kegiatan pembelajaran 
yang lebih menarik dan siswa dituntut untuk memvisualisasikan imajinasi mereka yang berkaitan dengan situs sejarah sebagai sumber belajar mereka. Hal tersebut akan meningkatkan peran aktif siswa di kelas sehingga diharapkan siswa akan lebih tertarik belajar sejarah dengan sumber belajar yang nyata dan lebih dekat dengan kebenaran.

Dewasa ini, dikalangan masyarakat termasuk kalangan pendidikan, memandang bahwa situs-situs sejarah hanya berfungsi sebagai tempat menyimpan atau pun sebagai bukti bahwa pernah ada

sebuah peninggalan di masa lampau. Akibatnya, tidak banyak guru di sekolah yang memanfaatkan situs sejarah tersebut sebagai sumber belajar bagi siswa dalam mata pelajaran sejarah. Bagi dunia pendidikan sebenarnya situs sejarah dapat menjawab sebuah persoalan atau pertanyaan yang muncul dalam proses pembelajaran terutama berkaitan dengan sejarah perkembangan manusia, budaya dan lingkungannya.

Situs sejarah sebagai sumber belajar dapat diartikan sebagai sebuah tempat atau wahana yang mampu memberikan pembelajaran kepada peserta didik. Situs sejarah merupakan tempat yang tepat sebagai sumber belajar khususnya pada mata pelajaran sejarah karena dianggap sebagai tempat yang tepat dalam memberikan simulasi maupun tempat yang bisa secara langsung memberikan gambaran pada peserta didik sehingga mereka bisa langsung memahami apa itu situs sejarah.

\section{Simpulan}

1. Situs cagar budaya di Minahasa sebagai sumber belajar sejarah Indonesia khususnya Pra Sejarah Indonesia. Situs Cagar budaya di Minahasa adalah "Waruga”(kubur batu), dan "watu tumotoa". Waruga adalah kubur batu dari zaman batu bagi orang Minahasa. Karena itu, kubur batu itu tersebar diberbagai daerah/wilayah di Minahasa. Bahkan keberadaannya di sekitar pemukiman masyarakat(penduduk). Pada masa pemerintahan Residen Deynse kebiasaan mngubur orang yang telah meninggal dalam kubur batu di Minahasa, dan berada disekitar rumah-rumah penduduk, mengalami perubahan karena telah dilarang dengan alasan kesehatan. Perubahan yang dilakukan berdasarkan alasan kesehatan dan agama maka orang yang sudah meninggal di kubur pada tempat khusus yang disebut lahan/ladang pekuburan. Sedangkan "watu tumotowa" atau "batu Manguni” juga terdapat di beberapa kampung sebagai tanda tempat leluhur mendengarkan

727 | Seminar Nasional Sejarah ke 4 Jurusan Pendidikan Sejarah Universitas Negeri Padang 
suara burung Manguni. Sehingga "watu tumotowa" ini ada kaitannya tempat mendengar suara yang memberikan petunjuk bahwa lokasi tersebut yang dapat dibangun kampung.

2. Proses pemanfaatan situs cagar budaya di Minahasa sebagai sumber belajar Sejarah Indonesia. Penggunaannya akan memberikan wawasan kepada mahasiswa tentang hasil karya leluhur pada zaman. Pada konteks kajian ini, yakni cara penguburan orang yang meninggal dan penandaan suatu tempat sebagai lokasi pendirian kampung atau tempat pemukiman. Proses pemanfaatan dapat dilakukan dengan 2 (dua) cara. Pertama, dapat langsung membelajarkan mahasiswa pada obyeknya dilakukan mahasiswa dengan mendapatkan bimbingan dosen. Khusus untuk mahasiswa dapat pula dilakukan dalam bentuk penugasan dosen secara kelompok dengan mengunjungi situs cagar budaya yang dekat dengan kampus. Namun demikian, cara pertama ini harus dilakukan melalui suatu perencanaan pembelajaran oleh dosen secara tepat pada topik yang relevan seperti topik zaman batu. Kedua, membelajarkan mahasiswa melalui foto atau gambar yang telah disiapkan dosen. Cara pembelajaran pertama dan kedua harus didahului dengan informasi dari dosen kepada mahasiswa. Dalam informasi awal telah dikemukakan kegiatan yang akan dilakukan di lokasi sesuai sejumlah pertanyaan kritis yang dijawab dengan melalui pengamatan pada situs budaya "waruga" dan "watu tumotoa".

\section{DAFTAR PUSTAKA}

Agus Mulyana \& Restu Gunawan., 2007. Sejarah Lokal Penulisan dan Pembelajaran di Sekolah. Salamina Press Bandung

Arif, Rahman, 2017, Pemanfaatan Situs Sejarah Sebagai Sumber Belajar di MA

Alma'arif Singosari Kabupaten Malang, Penelitian Kualitatif. Malang: Jurusan Pendidikan Ilmu Pengetahuan Sosial Fakultas Ilmu Tarbiyah dan Keguruan Universitas Islam Negeri Maulana Malik Ibrahim Malang.

Dadang Supardan., 2012. Pembelajaran Sejarah Berbasis Multikultural dan Perspektif Sejarah lokal, Nasional, dan Global Dalam Integrasi Bangsa. Bandung: Universitas Pendidikan Indonesia.

Hamalik, Oemar, 1985,Proses Belajar Mengajar. Jakarta: Rineka Cipta. 
Koentjaraningrat, 1981. Kebudayaan Mentalitas Dan Pembangunan. Jakarta. PT. Gramedia

Mona Lohanda., 2007. Sumber Sejarah Antara Kata, Bahasa Dan Penafsiran”. Bandung: Salamina Press.

Onibala Hendrik dan Pelealu A.E., 2007. Pengembangan Pariwisata Budaya Dalam Pelestarian Situs Cagar Budaya Di Minahasa Dan Minahasa Selatan. Unima. Manado

Rohani, Ahmad,2004, Pengelolaan Pengajaran,cet.,2. Jakarta: PT Rineka Cipta.

Said Hamid Hasan., 2012. Pendidikan Sejarah Indonesia: Isu dalam Ide dan Pembelajaran. Bandung:Rizqi Press.

Soekanto,Soerjono,1982, Sosiologi Suatu Pengantar. Jakarta:Rajawali Press.

Sondakh, L.W., 1984, Clove Production and Marketing in Relation to Agricultural Development in Minahasa, Sulawesi Utara, Working Paper. West Germany: Departement of Sociology Research Centre of Development Sociology,Univ.of Bielefeld. 